\title{
КОНЦЕПЦІЯ РЕАЛІЗАЦІї РЕГІОНАЛЬНОЇ ПОЛІТИКИ SMART-СПЕЦІАЛІЗАЦІЇ В УКРАЇНІ НА ЗАСАДАХ СТРУКТУРНО-ТЕХНОЛОГІЧНОЇ ПЕРЕБУДОВИ ${ }^{1}$

CONCEPT OF IMPLEMENTATION OF REGIONAL POLICY
OF SMART-SPECIALIZATION IN UKRAINE ON THE
PRINCIPLES OF STRUCTURAL AND TECHNOLOGICAL
RECONSTRUCTION

\author{
Васильців Тарас Григорович \\ доктор економічних наук, професор, \\ ДУ «Інститут регіональних досліджень імені М.І. Долішнього \\ Національної академії наук України» \\ ORCID: https://orcid.org/0000-0002-2889-6924 \\ Левицька Ольга Олександрівна \\ кандидат економічних наук, \\ ДУ «Інститут регіональних досліджень імені М.І. Долішнього \\ Національної академії наук України» \\ ORCID: https://orcid.org/0000-0001-8174-9918 \\ Vasyltsiv Taras, Levytska Olha \\ State Enterprise «Dolishniy Institute of Regional Research \\ of National Academy of Sciences of Ukraine»
}

\begin{abstract}
Стаття присвячена аспектам формування та реалізації державної політики смартспеціалізації регіонального розвитку. Аргументовано на тому, що реалізація політики смартспеціалізації має значно вищу ефективність за умови її орієнтації на пришвидшення інноваційно-технологічного розвитку, цифрровізацію та інтелектуалізацію, а також покращення структурних характеристик регіональних економічних систем. Вказано на недоліки перебігу процесів реалізації регіональної політики смартспеціалізації та структурно-технологічної перебудови в областях України. Обґрунтовано систему стратегічного інструментарію державної політики смартспеціалізації регіонів. Аргументовано на необхідності інституціалізації та реалізації в Україні Національної програми цифрової грамотності, Програми пріоритетних дій входження в інформаційне суспільство, Програми заходів з протидії кібершахрайству у фрінансовій сорері.

Ключові слова: регіональний розвиток, смартспеціалізація, інтелектуалізація та цифровізація, структура економіки, стратегування.
\end{abstract}

Статья посвящена аспектам формирования и реализации государственной политики смартспециализации регионального развития. Аргументировано, что реализация политики смартспециализации имеет значительно более высокую эффективность при ее ориентации на ускорение инновационно-технологическое развитие, цифровизацию и интеллектуализацию, а также улучшение структурных характеристик региональных экономических систем. Отмечены недостатки протекания процессов реализации региональной политики смартспециализации и структурно-технологической перестройки в областях Украины. Обоснована система стратегического инструментария государственной политики смартспециализации регионов. Аргументировано на необходимости институционализации и реализации в Украине Национальной программы цифровой грамотности, Программы приоритетных действий вхождения в информационное общество, Программы мер по противодействию кибермошенничестве в финансовой ссрере.

Ключевые слова: региональное развитие, смартспециализация, интелектуализация и цифровизация, структура экономики, стратегирование.

${ }^{1}$ Стаття підготовлена у межах виконання НдР «Методологічні засади smart-спеціалізації регіонів України» (номер державної реєстрації 0119U001869, 2019-2021рр.). 
The article is devoted to the aspects of formation and implementation of the state policy of smart specialization of regional development. It is shown that in the EU smart specialization is based on a partnership between representatives of business, government, scientific and technical institutions and the public in the development of key sectors of specialization in the region. At the same time, the priority is to stimulate projects aimed at ensuring the intellectualization and digital transformation of regional economies and society. It is argued that in Ukraine the implementation of smart specialization policy will be much more effective if it focuses on accelerating innovation and technological development, digitalization and intellectualization, as well as improving the structural characteristics of regional economic systems. The shortcomings of the processes of implementation of the regional policy of smart specialization and structural and technological restructuring in the regions of Ukraine are pointed out. In particular, such obstacles as insufficient level of infrastructure development of innovation and research, digitalization and implementation of its results in the real economy, the need for affordable investment, resistance of a number of actors to the introduction of modern information technologies, orientation of information and telecommunications for outsourcing, etc. The system of strategic tools of the state policy of smart specialization of regions is substantiated. It is argued on the need for institutionalization and implementation in Ukraine of the National Digital Literacy Program, the Program of Priority Actions for Entry into the Information Society, the Program of Measures to Combat Cyber Fraud in the Financial Sphere. The scientific novelty of the research results lies in the further development of conceptual provisions of strategic planning for the implementation of smart specialization policy in the regions of the state on the basis of structural and technological restructuring, in particular taking into account the typification of regions by level of innovation and technological development. The practical significance of the research results is that, depending on the degree of digitalization and intellectualization of regional economies, the appropriate type of strategy for further smart specialization with its own goals, objectives and means of achieving them is chosen.

Keywords: regional development, smart specialization, intellectualization and digitalization, economic structure, strategizing.

Постановка проблеми. Цифровізація та інтелектуалізація, що супроводжуються інтенсивним використанням нових знань і технологій, $є$ об'єктивною умовою розвитку таких ключових сорер господарювання та суспільного життя (що доведено практикою регіональної політики Європейського Союзу), як промисловість (високотехнологічне машинобудування, авіакосмічна інженерія, металургія, хімічна промисловість, радіоелектроніка, точне приладобудування, «зелена» енергетика тощо); транспорт (технології інтелектуальної транспортної системи та безпеки дорожнього руху, автоматичні транспортні пристрої, логістичні термінали, цифрові транспортні коридори, «хмарні» технології зберігання, обробки і віртуалізації даних); фрінансовий сектор (нові цисрові технології та послуги, комп'ютерне проектування, аналіз big data, blockchain, автоматизація, роботизація і використання штучного інтелекту); агропромисловий комплекс (розумні системи у сорері агровиробництва, інноваційні технології вирощування і переробки енергетичних культур, нові галузеві ніші); торгівля (е-комерція, онлайн-кредитування, smart-логістика, покращення цифрових компетентностей споживачів); IT-індустрія (передові цисррові рішення, зокрема дистанційний контроль, промисловий контроль, бізнес-додатки, кабельні технології, «хмарні» технології, супутникові технології тощо) та ін. Своєю чергою, перспективи реалізації принципів розумної спеціалізації у регіонах безпосередньо залежать від ресурсного забезпечення та інноваційно-технологічного потенціалу регіонів, пов'язаного з можливостями розвитку та впровадження нових знань і технологій у стратегічно важливих для регіональної економіки ссрерах господарювання. Відповідно, подальша ефективна політика реалізації регіональної політики смартспеціалізації в Україні на засадах структурно-технологічної перебудови потребує визначення чіткої концепції, на засадах якої буду вибудувано відповідний інструментарій управління в цій сорері.

Аналіз останніх досліджень і публікацій. Особливості фрормування та реалізації регіональної політики смартспеціалізації в країнах Європейського Союзу, зокрема на засадах структурно-технологічної перебудови, широко досліджуються у працях С. Давимуки, В. Куйбіди, Л. Федулової [1, с. 76-87] та ін. Аспектам та чинникам інноваційно-технологічного розвитку, а також структурного рефрормування національних економік присвячені результати досліджень Т. Васильціва, Р. Лупака та В. Рудковського [2, с. 162-169], Т. Штець [3, с. 33-39], О. Пришляка [4, с. 271-277], О. Сербіна [5, с. 1-2] та ін. науковців. Інструменти державної політики стимулювання розвитку та реалізації потенціалу креативного сектора регіональних економік достатньо комплексно розкриті у працях І. Вахович та О. Чуль [6, с. 182-186], Т. Постнової, О. Химороди, Н. Тершак [7, с. 81-87], О. Тімоніна та Ю. Сиваш [8, с. 177-181] та ін. Проте, динамічні умови, сучасні виклики та загрози, а також все ще низька ефективність вітчизняної 
регіональної інноваційно-технологічної політики обґрунтовують актуальність фрормування нових концепцій реалізації регіональної політики smart-спеціалізації в Україні на засадах структурно-технологічної перебудови.

Формулювання цілей статті. Метою статті є обґрунтування нових концепцій реалізації регіональної політики smart-спеціалізації в Україні на засадах структурно-технологічної перебудови.

Виклад основного матеріалу. Багато «цисрових» та інноваційно-інтелектуальних ініціатив в Україні, які фрормують умови для проникнення технологій та новацій у різні сорери економіки, вже імплементовано або знаходяться на початковому етапі реалізації. Важливо підкреслити, що Україна має суттєву підтримку європейської спільноти у цьому напрямку. Для прикладу, уряд ратифрікував Угоду про фрінансування заходу «Підтримка $€ С$ для електронного урядування та циоррової економіки в Україні» (розпорядження № 52-р від 24.01.2020р.), чим потенційно посилив національну технологічну конкурентоспроможність і наблизив українське суспільство до інтеграції у європейське співтовариство.

Водночас, очевидні позитивні зрушення приховують цілу низку ризиків та загроз, котрі варто враховувати при фрормуванні та імплементації інноваційної, «циорової», секторальної, структурної та регіональної політики держави на засадах smart-підходу. Потенційні «вузькі місця» у процесах цифррової трансорормації та інноваційно-технологічної перебудови України, перш за все, стосуються: неготовності суспільства до повноцінного використання цифррових технологій через низьку цифрову грамотність, недостатньої економічної спроможності населення і шаблонності мислення; низької технологічної готовності бізнесу; незахищеності даних і недостатнього забезпечення кібербезпеки держави; незрілості ринку інтелектуальної власності та ненадійності захисту інтелектуальних продуктів; структурної інертності окремих секторів економіки, зокрема промисловості; прекаризації (незахищеності) праці у результаті появи атипових фрорм зайнятості в офріційному та тіньовому сегментах ринку праці.

Ще однією проблемою на шляху циорровізації та інтелектуалізації економіки України є інституціональні недоліки, зокрема декларативність та фррагментарність загальнодержавних і галузевих стратегій (програм) розвитку, недостатність їх на регіональному рівні, відсутність досвіду у напрацюванні есрективних і динамічних smartстратегій для окремих регіонів чи громад.
Інституціональні виклики можуть бути частково нівельовані завдяки врахуванню їх у програмно-цільових документах стратегічного значення 3 подальшою імплементацією конкретних цілей і завдань, що актуалізує розробку та прийняття Концепції реалізації регіональної політики смартспеціалізації в Україні на засадах структурно-технологічної перебудови, що закладе фундамент прийняття таких документів, як Національна програма цифррової грамотності, Програма пріоритетних дій входження в інсормаційне суспільство, Програма заходів 3 протидії кібершахрайству у фрінансовій сфрері (для унеможливлення використання сучасних технологій в цілях ухилення від сплати податків, виведення капіталу в офршорні юрисдикції, валютно-митних спекуляцій).

У контексті регіональної економіки програмно-цільове планування $\epsilon$ важливою ланкою складного механізму сталого smartорієнтованого розвитку регіонів з врахуванням процесів циорровізації та інтелектуалізації, що відбуваються в Україні та у світі загалом.

Інституціалізація відповідної державної політики передбачає врахування визначених цільових орієнтирів 3-поміж положень Державної стратегії регіонального розвитку на 2021-2027 роки (стратегічна ціль II. Підвищення рівня конкурентоспроможності регіонів), а також доповнення Плану заходів на 2021-2023 роки з реалізації стратегії (операційна ціль 4. Сприяння впровадженню інновацій та зростанню технологічного рівня регіональної економіки, підтримка інноваційних підприємств та стартапів).

Відповідний механізм передбачає фрормування стратегічних цілей (пріоритетів) та конкретних інструментів реалізації ідей інноваційно-цифррової перебудови. Генеральною метою такого стратегування визначено структурну перебудову економіки регіонів на засадах інтелектуалізації та цифрровізації. Досягненню цієї мети сприятиме імплементація трьох важливих напрямів сталого регіонального розвитку, пов'язаних з інтелектуалізацією економіки (передбачає креативізацію і формування нових знань), цифровізацією суспільства (включає побудову цисррової держави, суспільства і ринку), інноваційним розвитком (забезпечує підвищення технологічної конкурентоспроможності).

Конкретні кроки та інструменти реалізації задекларованих smart-цілей мають розроблятися із врахуванням інноваційного потенціалу і технологічної озброєності конкретного регіону, а також наявних у нього конкурентних переваг. Такий поділ доцільно здійснити 3 виділенням трьох груп регіонів на основі клас- 
терного аналізу: інноваційно активні області 3 високим інтелектуально-цифровим потенціалом (тип А); регіони, частково орієнтовані на інновації із середнім інтелектуально-цифровим потенціалом (тип В); інноваційно пасивні області з низьким інтелектуально-цифровим потенціалом (тип С). Такий підхід дає можливість визначати пріоритетні види економічної діяльності у регіоні, котрі генерують і активно використовують (або потенційно здатні генерувати і використовувати) інноваційні технології та інтелектуально-креативні ресурси. Важливими інструментами в контексті фрормування нових перспектив регіонального розвитку і повноцінної європейської інтеграції $€$ фрормування ринку інтелектуальної власності, створення системи транссреру знань і технологій, введення міжнародних стандартів обміну даними (CRS, FATCA та ін.), подальша цисровізація державного управління і соціальної сфери, підвищення «цифрової готовності» і грамотності суспільства, зміцнення його креативного потенціалу, покращення іміджевих характеристик регіонів та їх міжнародної інвестиційної привабливості.

Результатами застосування smart-підходу до стратегічного планування розвитку регіонів повинні бути модернізація промисловості і її перехід на новий технологічний уклад, активізація інноваційно-технологічного та «цифрового» потенціалу територій, розвиток нових драйверів регіональної економіки, зміщення «центрів інновацій» 3 великих підприємств до малих (стартапів і бізнес-проектів), позитивні зрушення на регіональному ринку праці у бік орлексик'юризації, що ґрунтується на нових концепціях праці, нестандартній зайнятості, сучасних компетентностях і соціально-трудовій захищеності.

Першочерговим завданням постає «мапінг» інтелектуально-креативного, цифрового та інноваційного потенціалу для реалізації цілей smart-підходу. Перелік стратегічних цілей та взаємозалежність між ними узагальнюється у форматі стратегічної карти регіонального розвитку, розробленої із урахуванням пріоритетних показників розвитку регіонів у контексті інтелектуалізації, цифрровізації та інноватизації економіки. На карті конкретизуються заходи щодо досягнення головних цілей на рівні тактичного планування.

Реалізація стратегічних цілей потребує, окрім наявних у регіонах ресурсів, знань та можливостей, покращення стану, удосконалення або створення нових. У такому випадку застосовується допоміжна перспектива, що конкретизує стратегічні програми фрормування та розвитку конкурентних переваг регіону через кількісні та якісні показники (наприклад, частка інноваційно активних підприємств, відсоток науково-технічних і креативних кадрів, кількість патентів на винаходи, частка впроваджених нових технологічних процесів на промислових підприємствах тощо).

Загальна стратегічна карта регіонального розвитку повинна доводитися до відома органів місцевого самоврядування шляхом ії розгортання (декомпонування) на нижчі рівні (стратегічні карти другого, третього та інших рівнів).

Напрацювання і відповідно впровадження більш ефективних інструментів інтелектуалізації та цифровізації регіонального розвитку у відповідності до Концепції реалізації регіональної політики смартспеціалізації в Україні на засадах структурно-технологічної перебудови дозволить не лише підвищити регіональну конкурентоспроможність, створити нові робочі місця, покращити якість життя населення та зміцнити імідж регіонів в цілому, а й отримати додаткову фрінансову підтримку регіонального розвитку, зокрема пріоритетних секторів економіки, завдяки підвищенню інвестиційної привабливості територій. Ще однією перевагою $є$ можливість долучення до програмних ресурсів європейських фондів (Horizon 2020, Cosme, Enterprise Europe Network та ін.) і розширення зовнішніх джерел фрінансування розвитку регіону. Це дає реальну можливість налагодження єврорегіональної співпраці - партнерства з європейськими регіонами, що мають суміжну спеціалізацію, і відповідно сприяє долученню до європейських ланцюгів доданої вартості.

Висновки. Політика смартспеціалізації регіонального розвитку, що реалізується в Україні, все ще не досягла своїх цілей, адже рівень інтелектуалізації та цифрровізації регіональних економік все ще низький, можливості високотехнологічного виробництва та експорту обмежені, а поширення цифрових комунікацій в суспільстві та бізнесі - обмежене. Подальший поступ зрушень в цій сорері потребує нових підходів до стратегічного планування, що актуалізує розробку Концепції реалізації регіональної політики смартспеціалізації в Україні на засадах структурно-технологічної перебудови, згідно якої будуть утверджені диференційовані цілі та інструменти інтелектуалізації та цифровізації регіонального розвитку у фрокусі нових перспектив смартспеціалізації в Україні залежно від типу регіону за рівнем інноваційно-технологічного розвитку; ссрормовані стратегічні карти інтелектуалізації та цисрровізації регіонального 
розвитку у фрокусі нових перспектив smartспеціалізації в регіонах України; напрацьовані i, відповідно, впроваджені більш ефективні інструменти інтелектуалізації та цифровізації регіонального розвитку. Це дозволить не лише підвищити регіональну конкурентоспромож- ність, створити нові робочі місця, покращити якість життя населення та зміцнити імідж регіонів в цілому, а й отримати додаткову фрінансову підтримку регіонального розвитку, зокрема пріоритетних секторів економіки, завдяки підвищенню інвестиційної привабливості територій.

\section{СПИСОК ВИКОРИСТАНИХ ДЖЕРЕЛ:}

1. Давимука С. А., Куйбіда В. С., Федулова Л. І. Тенденції розвитку нової регіональної політики країн-членів Європейського Союзу. Регіональна економіка. 2019. № 1(91). С. $76-87$.

2. Васильців Т. Г., Лупак Р. Л., Рудковський О.В.Роль сектору інформаційно-комунікаційних технологій у формуванні та реалізації потенціалу smart-спеціалізації на регіональному рівні. Держава та регіони. 2019. № 5(110). C. 162-169.

3. Лупак Р. Л., Штець Т. Ф. Стратегічне програмування державної політики цисрровізації реального сектору економіки України. Економіка та держава. 2020. № 1. С. 33-39.

4. Лупак Р. Л., Штець Т. Ф., Пришляк О. П. Інституціональні аспекти державного регулювання розвитку цифрової економіки України. Бізнес Інфрорм. 2020. № 1. С. 271-277.

5. Сербін О., Галаган Л. Інновації в науці як чинник розвитку знаннєвого середовища. Вісник Книжкової палати. 2012. № 5. С. 1-2.

6. Вахович І. М., Чуль О. М. Розвиток креативної економіки в умовах транскордонного співробітництва. Проблеми економіки. 2014. № 3. C. 182-186. URL: http://nbuv.gov.ua/UJRN/Pekon_2014_3_24

7. Поснова Т. В., Химорода О. П., Тершак Н. А. Креативна економіка: сутність, особливості та передумови формування. Международный научный журнал «Интернаука». 2018. № 3(43). Т. 2. С. 81-87.

8. Тімонін О. М., Сиваш Ю. М. Креативність як чинник інноваційної діяльності підприємств. Причорноморські економічні студії. 2016. Вип. 11. С. 177-181.

\section{REFERENCES:}

1. Davymuka, S. A., Kyibida, V. S. \& Fedulova, L. I. (2019) Tendenciyi rozvytku novoyi regionalnoyi polityky krayin-chleniv Evropeyskogo soyuzu [Trends in the development of new regional policies of the European Union member states]. Regional economy, 1(91), 76-87. DOI: https://doi.org/10.36818/1562-0905-2019-1-9 (in Ukrainian)

2. Vasyltsiv, T. G., Lupak, R. L. \& Rudkovskyi, O. V. (2019) Rol sektoru informaciyno-komunikaciynyh tehnologiy u formuvanni ta realizaciyi potencialu smart-specializaciyi na regionalnomu rivni [The role of the information and communication technology sector in the formation and implementation of the potential of smart specialization at the regional level]. State and regions, 5(110), 162-169. DOI: https://doi.org/10.32840/1814-1161/2019-5-30 (in Ukrainian)

3. Lupak, R. L. and Shtets, T. F. (2020) Strategichne programuvannia derzhavnoyi polityky cyfrovizaciyi realnogo sektoru ekonomiky Ukrainy [Strategic programming of the state policy of digitalization of the real sector of the economy of Ukraine]. Economy and state, 1, 33-39. DOI: https://doi.org/10.32702/2306-6806.2020.1.33 (in Ukrainian)

4. Lupak, R. L., Shtets, T. F. \& Pryshliyak, O. P. (2020) Instutycionalni aspekty derzhavnogo regulyuvannia rozvytku cyfrovoyi ekonomiky Ukrainy [Institutional aspects of state regulation of digital economy development in Ukraine]. Biznes-Inform, 1, 271-277. DOI: https://doi.org/10.32983/2222-4459-2020-1-271-277 (in Ukrainian)

5. Serbin, O. and Galagan, L. (2012). Innovaciyi v nauci yak chynnyk rozvytku znannyevogo seredovyshcha [Innovations in science as a factor in the development of the knowledge environment]. Bulletin of the Book Chamber, no. 5, 1-2. Available at: http://nbuv.gov.ua/UJRN/vkp_2012_5_12 (in Ukrainian)

6. Vakhovych, I. M. \& Chul, O. M. (2014) Rozvytok kreatyvnoyi ekonomiky v umovah transkordonnogo spivrobitnytstva [Development of creative economy in conditions of cross-border cooperation]. Problems of economy, 3 , 182-186. Available at: http://www.problecon.com/export_pdf/problems-of-economy-2014-3_0-pages-182_186.pdf (in Ukrainian)

7. Posnova, T. V., Hymoroda, O. P. \& Tershak, N. A. (2018) Kreatyvna ekonomika: sutnist, osoblyvosti ta peredumovy formuvannia [Creative economy: essence, features and preconditions of formation]. International science journal «Internauka», 3(43), 81-87. Available at: http://nbuv.gov.ua/UJRN/mnj_2018_3\%282\%29_21 (in Ukrainian)

8. Timonin, O. M. and Syvash, Yu. M. (2016) Kretyvnist yak chynnyk innovaciynoyi diyalnosti pidpryemstv [Creativity as a factor of innovative activity of enterprises]. Prychornomorian economical studies, 11, 177-181. Available at: http://nbuv.gov.ua/UJRN/bses_2016_11_40 (in Ukrainian) 